\title{
EDUHAT : Edukasi Hipertensi Dengan Pola Hidup Sehat Pada Kelompok Petani Mina Padi Sambe Rembe Pakem Yogyakarta
}

\author{
Rudi Haryono, Etik Pratiwi, Taukhit \\ Sekolah Tinggi Ilmu Kesehatan Notokusumo Yogyakarta \\ Email: rhudee fukuza@yahoo.com
}

\begin{abstract}
Abstrak
Latar Belakang: Hipertensi merupakan salah satu penyakit degeneratif yang saat ini dialami baik oleh usia dewasa awal maupun lanjut usia. Kelompok tani Mina Padi memiliki usia rata-rata pada lansia yang memiliki risiko hipertensi tinggi dan jarang melakukan pengawasan kesehatan di dinas kesehatan setempat Metode: Kegiatan dilakukan dengan metode kuasi eksperimental yaitu dengan melakukan penyehatan. olah raga pengobatan hipertensi dan ukur tekanan darah, serta penyuluhan tentang hipertensi dan budaya hidup sehat. Kegiatan berlangsung pada 6-7 Agustus 2020 di Aula Sekretariat Kelompok Tani Mina Padi Sambe Rambe. Responden dalam kegiatan ini berjumlah 18 orang yang terdiri dari anggota kelompok, kelompok penyuluh pertanian pendamping dan perwakilan dari Desa Candibinagun. Hasil: Terdapat 27,78\% responden mengalami hipertensi derajat I, 55,5\% responden mengalami hipertensi derajat II, dan 16,67\% memiliki tekanan darah normal. Responden berusia 45-59 tahun sebanyak 55,5\%, dewasa $33,33 \%$, dan usia lanjut $11,12 \%$ yaitu 60-74 tahun. Sebagian besar anggota kelompok sudah mengetahui pengetahuan tentang hipertensi yaitu $66,66 \%$. Sebanyak $33,44 \%$ petani memiliki pengetahuan yang cukup tentang hipertensi. Semoga kegiatan pengabdian masyarakat ini dapat meningkatkan budaya sehat masyarakat khususnya pada kelompok tani Mina Padi.
\end{abstract}

Kata Kunci: Hipertensi, Makanan Sehat, dan Senam Sehat

\section{Abstract}

Background : Hypertension is a degenerative disease that is currently experienced by both early adulthood and also the elderly. The Mina Padi farmer group has an average age towards the elderly who have a high risk of hypertension and they rarely carry out health control at the local health service.Methods: The activity was carried out with a quasi-experimental method, namely by conducting healthy exercise treatment of hypertension and measuring blood pressure, and counseling about hypertension and healthy living culture. The activity took place on 6-7 August 2020 at the Hall of the Secretariat of the Mina Padi Sambe Rambe Farmer Group. There were 18 respondents in this activity consisting of group members, group companion agricultural extension workers and representatives from the Candibinagun Village. Result : There were $27.78 \%$ respondents who had 1st degree hypertension, 55.5\% respondents had 2nd degree hypertension, and $16.67 \%$ had normal blood pressure. Respondents aged $45-59$ years were $55.5 \%, 33.33 \%$ were adults, and $11.12 \%$ of respondents were elderly, namely $60-74$ years. Most of the group members already knew about hypertension knowledge, which was $66.66 \%$. As many as $33.44 \%$ of farmers

http://ejournal.urindo.ac.id/index.php/PAMAS

Article History : 


\section{Jurnal Pelayanan dan Pengabdian Masyarakat (PAMAS)}

have sufficient knowledge about hypertension. Hopefully this community service activity can improve the healthy culture of the community, especially in the Mina Padi farmer group.

Keywords: Hypertension, Healthy Food, and Healthy Gymnastics

\section{PENDAHULUAN}

Kelompok Tani Mina Padi Sambe Rembe merupakan kelompok tani berjumlah 40 orang yang terletak di kaki Gunung Merapi yang berjarak sekitar 20 KM dari Perguruan Tinggi. Didesa ini mayoritas masyarakat bermata pencaharian petani dengan kemampuan ekonomi menengah kebawah.

Dikampung ini mayoritas petani menanam padi. Selain padi, petani di Sambe Rembe juga menanam tanaman hortikultura seperti tomat, kacang, pare, gambas, timun, terong, dan sawi hingga komoditas yang jarang dibudidayakan petani lokal seperti buah semangka dan melon.

Masyarakat mendapatkan pelayanan kesehatan dari area Puskesmas dan mayoritas masyarakat jarang yang mendapatkan layanan kesehatan untuk screening pencegahan penyakit. Petani di area ini kebayakan adalah Lansia dan Bapak-Bapak usia produktif. Usia petani di area ini antara 30 tahun hingga 50 tahun. Para petani di area ini enggan untuk pergi keluar kota dan lebih menyukai bekerja di kampung sendiri untuk mengembangkan area pertanian yang dimiliki. Fenomena penyakit tertinggi yang saat ini berkembang khususnya di daerah Sambe Rembe adalah hipertensi. Aktifitas petani memang melibatkan kegiatan fisik, akan tetapi sangat berbeda dengan definisi olahraga untuk kebugaran. Dimana makna dari olah raga ini harus terprogram dengan ritme yang teruji secara kesehatan dan mampu memperbaiki suasana hati. Rata-rata para petani ini jarang sekali atau bahkan banyak yang tidak pernah memiliki program olahraga terprogram seperti ini. Olahraga dapat digunakan sebagai terapi tambahan untuk penderita hipertensi. Diharapkan dengan mengikuti senam secara teratur dan terprogram bisa menurunkan hipetensi dan sebagai pengobatan gteratur, yakni dengan latihan jasmani (1)

Hiperkolesterolemia tidak dapat diatasi dengan latihan jasmani saja, namun bersamasama dengan perubahan susunan makanan yang sehat (2)

Berdasarkan hasil survei kesehatan, para petani rata-rata jarang dilakukan pemeriksaan kesehatan, dan kesadaran untuk menjaga kesehatannya cukup minim. Kegiatan 
Posyandu Lansia tidak pernah diadakan dalam 1 tahun ini, dikarenakan minimnya tenaga kesehatan yang ada di wilayah area Candibinangun, Pakem Sleman khususnya di area Sambe Rembe. Para petani tersebut setiap hari dituntut untuk bekerja secara fisik.

Hipertensi ini dapat menyebabkan komplikasi kesehatan yang parah dan meningkatkan risiko penyakit jantung, stroke, dan terkadang kematian. Tekanan ini tergantung pada resistensi pembuluh darah dan seberapa keras jantung bekerja. Semakin banyak darah yang dipompa jantung dan semakin sempit arteri, maka semakin tinggi tekanan darah (3).

Gaya hidup para kelompok tani ini adalah sering mengkonsumsi makanan tinggi garam, mengkonsumsi kopi, merokok, dan jarang berolah raga. Permasalahan tersebut merupakan kondisi sehingga penting dilakukan kegiatan pengabdian masyarakat ini. tim pengabdian masyarakat melakukan koordinasi dengan kelompok tani untuk mengumpulkan kelompok tersebut dalam suatu waktu kegiatan. Kegiatan berisi serangkaian aktivitas sebagai berikut : melakukan screening kesehatan yakni pemeriksaan tekanan darah para petani., melakukan penjelasan makanan sehat dan gaya hidup sehat kepada para petani, pemberian makanan sehat yakni makanan dengan rendah garam dan rendah protein, melakukan screening kolesterol sebagai salah satu faktor resiko terjadinya hipertensi.Memberikan edukasi senam sehat untuk menurunkan resiko penyakit hipertensi.

luaran kegiatan ini adalah adanya pemahaman para petani terhadap pencegahan hipertensi dan penerapan gaya hidup sehat melalui evaluasi quesioner pemahaman dan monitoring tekanan darah, kolesterol setelah dilakukan pengabdian masyarakat.

\section{KAJIAN LITERATUR}

Hipertensi merupakan masalah besar yang menjadi tantangan bagi pelayanan kesehatan di Indonesia. Hasil Riset Kesehatan Dasar (Riskesdas) tahun 2013 menunjukan prevalensi hipertensi di Indonesia masuk dalam kategori sedang yaitu sebesar 25,8\% (Riskesdas, 2013). Data hipertensi di Jawa Tengah pada tahun 2015 menurut profi I kesehatan provinsi mencapai

\section{$57,78 \%$ kasus}

Meskipun demikian, data Profi I Kesehatan Kota menunjukkan bahwa di Kota Salatiga pada tahun 2014 ditemukan prevalensi hipertensi sebanyak 62\%. Apabila penyakit hipertensi tidak ditangani dengan baik maka dapat menimbulkan PTM lanjutan seperti stroke, jantung, gagal 
ginjal, dan penyakit kardiometabolik lainnya. (4)

Berdasarkan penyebabnya, hipertensi dibagi dua golongan yaitu hipertensi esensial yang tidak diketahui penyebabnya dan hipertensi sekunder yang diketahui penyebabnya seperti gangguan ginjal, gangguan hormon, dan sebagainya.(5).

Ada beberapa hal yang memperngarui hipertensi. Faktor risiko yang mempengaruhi kejadian hipertensi pada responden diwilayah kerja Puskesmas Sidorejo Lor yaitu jenis kelamin, pekerjaan, riwayat hipertensi, pola konsumsi (frekuensi makan, jenis makanan dan hiet hipertensi), asupan gizi dan Indeks Massa Tubuh (IMT). Namun hasil penelitian tidak ditemukan adanya keterkaitan antara kejadian hipertensi dengan kebiasaan merokok dan olahraga.(6).

Makanan yang dikonsumsi merupakan faktor penting yang dapat mempengaruhi tekanan darah .Terlalu sering mengonsumsi makanan yang diawetkan, mengonsumsi garam berlebih serta penggunaan bumbu penyedap seperti monosodium glutamat (MSG) dalam jumlah yang tinggi dapat mengakibatkan kenaikan tekanan darah karena banyaknya natrium yang terkandung dalam makanan tersebut. Konsumsi natrium berlebih dapat menahan air (retensi) sehingga terjadi peningkatan jumlah volume darah, yang karena peningkatan jumlah volume darah tersebut jantung harus bekerja lebih keras untuk memompanya dan tekanan darah menjadi naik (7)

\section{METODE PENELITIAN}

Desain dalam proses kegiatan ini adalah menggunakan desain quasi eksperimental design, yakni dengan memberikan kegiatan penyuluhan tentang budaya hidup sehat, pemberian senam sehat, dan melakukan pengukuran tekanan darah.

Proses pengambilan data dalam kegiatan pengabdian masyarakat ini dilakukan dengan beberapa tahapan sebagai berikut adalah sebagai berikut : pelaksanaan tahap 1: Koordinasi pelaksanaan dengan Koordinator Kelompok Tani Mina Padi (Focus Group Discation/FGD). Sebelum dilakukan pelaksanaan kegiatan pengabdian masyarakat terlebih dahulu dilakukan kegiatan koordinasi dan diskusi dengan koordinator kelompok mina padi sambe rambe. Dari hasil koordinasi tersebut didapatkan beberapa hasil sebagai berikut: kegiatan pengabdian masyarakat dapat sesuai dengan kelompok sasaran, karena mayoritas anggota kelompok berada di kelompok lansia, disepakati kegiatan akan dilaksanakan di pendopo sekertariat Kelompok Mina Padi Sambe Rambe pada tanggal 7 Agustus 2020. 
Pelaksanaan kegiatan disepakati dengan runtutan kegiatan sebagai berikut :screening tekanan darah anggota kelompok, pengukuran tingkat pengetahuan anggota kelompok tentang hipertensi , penyuluhan hipertensi, pelatihan senam antihipertensi .

Pelaksanaan pada tahap II : kegiatan pengabdian masyarakat dilaksanakan pada tanggal 7 Agustus 2020 pukul 12.30-17.00 WIB di Pendopo sekertariat Kelompok Tani Mina Padi Sambe Rambe dengan dihadiri oleh anggota kelompok, penyuluh pertanian pendamping kelompok dan perwakilan dari Perangkat Desa Candibinagun.Kegiatan dilaksanakan dengan runtutan kegiatan sebagai berikut:screening tekanan darah anggota kelompok, pengukuran tingkat pengetahuan anggota kelompok tentang hipertensi, penyuluhan hipertensi, pelatihan senam antihipertensi . Kegiatan ini telah mendapatkan ijin dari institusi Sekolah Tinggi Ilmu Kesehatan Notokusumo Yogyakarta dengan nomor ijin 132/ST.11.02/2020.

\section{HASIL PENELITIAN}

Kegiatan pengabdian masyarakat dilakukan dengan hasil sebagai berikut

Tabel 2. Hasil Klasifikasi Tekanan Darah

Kelompok Tani Mina Padi Sambe Rambe ( $n=18)$

\begin{tabular}{llll}
\hline No & Klasifikasi Tekanan Darah & Frekuensi & Persentase \\
\hline 1 & Normal & 3 & $16,67 \%$ \\
\hline 2 & Prahipertensi & 0 & 0 \\
\hline 3 & Hipertensi derajat 1 & 5 & $27,78 \%$ \\
\hline 4 & Hipertensi derajat 2 & 10 & $55,55 \%$ \\
\hline
\end{tabular}

Dari hasil tersebut dapat diketahui bahwa sebagian besar anggota Kelompok Tani Mina Padi Sambe Rambe menderita hipertensi dengan pembagian 27,78\% masuk kategori hipertensi derajad 1 dan 55,55\% masuk dalam kategori hipertensi derajat 2.

Tabel 3. Gambaran Usia Anggota Kelompok Tani Mina Padi Sambe Rambe $(n=18)$

\begin{tabular}{llll}
\hline No & Klasifikasi Usia & Frekuensi & Persentase \\
\hline 1 & Usia Dewasa & 6 & $33.33 \%$ \\
\hline 2 & Usia Pertengahan (45-59 tahun) & 10 & $55,55 \%$ \\
\hline 3 & Usia Lanjut (60-74 tahun) & 2 & $11,12 \%$ \\
\hline
\end{tabular}


Jurnal Pelayanan dan Pengabdian Masyarakat (PAMAS)

Pada Tabel 3 tersebut dapat disimpulkan bahwa Usia Paling banyak adalah 55,55\% yakni berusia 45-59 tahun .

Tabel 4.Gambaran Pengetahuan Anggota Kelompok Tani Mina Padi Sambe Rambe tentang Hipertensi

\begin{tabular}{llll}
\hline No & Kategori Pengetahuan & Frekuensi (f) & Persentase (\%) \\
\hline 1 & Baik & 12 & $66,66 \%$ \\
2 & Cukup & 6 & $33,44 \%$ \\
3 & Kurang & 0 & - \\
\hline
\end{tabular}

Berdasarkan tabel di atas dapat diketahui bahwa secara pengetahuan sebagian besar anggota kelompok sudah mengetahui tentang hipertensi yaitu sebesar $66,66 \%$. Sebanyak $33,44 \%$ petani memiliki pengetahuan cukup tentang hipertensi.

\section{PEMBAHASAN}

Hipertensi adalah suatu penyakit dimana terjadi peningkatan tekanan darah yang menetap dengan atau tanpa disertai gejala-gejala tertentu. ${ }^{4}$ Brunner dan Suddarth ${ }^{5}$, mendefinisikan hipertensi sebagai tekanan darah persisten dimana tekanan sistoliknya di atas $140 \mathrm{mmHg}$ dan tekanan diastolik di atas $90 \mathrm{mmHg}$. The Sixt Report of the Joint National Committee on Prevention, Detection, Evaluation and Treatment of High Blood Pressure (1997), menyatakan bahwa yang dimaksud dengan hipertensi adalah apabila tekanan darah sistoliknya sama atau diatas $140 \mathrm{mmHg}$ atau tekanan darah distoliknya sama atau diatas $90 \mathrm{mmHg}$.

Dari Tabel 1 dan Tabel 2 tersebut dapat diketahui bahwa sebagian besar anggota Kelompok Tani Mina Padi Sambe Rambe menderita hipertensi dengan pembagian 27,78\% masuk kategori hipertensi derajad 1 dan 55,55\% masuk dalam kategori hipertensi derajat 2. Tingginya angka penderita hipertensi pada anggota kelompok Tani Mina Padi Sambe Rambe tersebut kemungkinan besar berkaitan dengan faktor usia, mengingat mayoritas anggota kelompok berusia lansia kategori pertengahan sebesar $55,55 \%$.

Hipertensi merupakan salah satu penyakit kardiovaskular yang sering dijumpai. Pravelensi hipertensi meningkat seiring dengan meningkatnya umur(8). Menurut (9), jumlah individu yang mengalami hipertensi meningkat sejalan dengan meningkatnya usia dan lebih banyak dijumpai pada orang kulit hitam dibanding orang kulit putih. Pravelensi hipertensi pada usia di bawah 40 
tahun kurang dari 10\%. Tetapi pada golongan umur 50 tahun ke atas angka ini naik menjadi $20 \%$ atau lebih.(10)

Hasil penelitian Rogers yang dikutip kembali oleh (11), menyatakan bahwa pengetahuan atau kognitif merupakan domain yang sangat penting untuk terbentuknya tindakan seseorang. Perilaku yang didasari oleh pengetahuan dan sikap yang positif maka perilaku tersebut akan bersifat langgeng. Menurut Penelitian (12), faktor yang dominan mempengaruhi strategi koping penderita hipertensi di dusun Bakalan dan Jumeneng Kidul Sumberadi Mlati Sleman adalah tingkat pengetahuan.

Pada tahap awal kegiatan pengabdian masyarakat dilakukan pengukuran tingkat pengetahuan tentang hipertensi pada anggota Kelompok Tani Mina Padi Sambe Rambe. Pada program pengabdian masyarakat yang dilaksanakan dengan judul EDUHAT : : Edukasi Hipertensi dengan Pola Hidup Sehat " Pada Kelompok Petani Mina Padi di Kampung Sambe Rembe Pakem Candibinangun Sleman Yogyakarta" diharapkan dapat memberikan pengetahuan kepada anggota kelompok tentang kontrol kenaikan tekanan darah dengan cara pola hidup sehat. Hal tersebut sangat penting mengingat petani merupakan salah satu sektor utama dalam ketahan pangan. Produktivitas seorang petani sangat berkaitan dengan kualitas kesehatan, sedangkan kondisi hipertensi yang dialami anggota kelompok dengan data 27,78\% masuk kategori hipertensi derajat 1 dan 55,55\% masuk dalam kategori hipertensi derajat 2 jika tidak dikelola akan berdampak pada penyakit komplikasi hipertensi dan mengurangi produktivitas petani.

\section{KESIMPULAN}

Pada program EDUHAT : : Edukasi Hipertensi dengan Pola Hidup Sehat diberikan edukasi kepada anggota kelompok tentang beberapa hal sebagai berikut: agar penderita hipertensi tidak sampai terjadi komplikasi atau menjaga agar orang yang sehat terhindar dari penyakit Hipertensi Beberapa hal yang bisa dilakukan setelah program EDUHAT ini diantranya adalah anjuran pola hidup sehat dengan cara mencegah beberapa hal yaitu obesitas, makanan tinggi kolesterol, Konsumsi tinggi natrium/garam, merokok. Adanya petugas keehatan yang secara teratur datang dalam kegiaatan rutin pertemuan. Pengecekan kesehatan rutin khususnya pengecekan tekanan darah rutin bagi para petani sambe rembe dengan melakukan kerja sama dengan kader lansia di area setempat. Adanya pemberian informasi edukasi mengenai hipertensi ecara teratur melalui koordinator lapangan agar para petani selalu ingat untuk melakukan budaya hidup sehat 


\section{UCAPAN TERIMA KASIH}

Kami mengucapkan terimakasi kepada Gabungan Kelompok Tani Mina Padi Sambe Rembe yang bersedia bekerja sama dalam program EDUHAT ini. Selain itu kami berterimakasih pula kepada Lembaga Penelitian dan Pengabdian Masyarakat Stikes Notokusumo Yogyakarta yang mendukung program pengambdian masyarakat ini.

\section{DAFTAR RUJUKAN}

1. Rismayanti C. Penurunan tekanan darah pada penderita hipertensi melalui senam aerobic low impact. J IImu Kesehat Olahraga. 2011;VII(1).

2. Annonim. Tekanan Darah Tinggi. 2008; Available from: www.jantunghipertensi.com

3. Harvard Health. High Blood pressure (Hypertension). 2020.

4. Dinas Kesehatan Kota Salatiga. Profi I Kesehatan Kota Salatiga Tahun 2014. In 2015.

5. Anggara D dan PN. Faktor-Faktor Yang Berhubungan Dengan Tekanan Darah di Puskesmas Telaga Murni Cikarang Barat Tahun 2012. J Ilmu Kesehatan Vol. 2013;5(1):5-20.

6. Nugroho KPA, Sanubari TPE, Rumondor JM. Faktor Risiko Penyebab Kejadian Hipertensi Di Wilayah Kerja Puskesmas Sidorejo Lor Kota Salatiga. J Kesehat Kusuma Husada. 2019;32-42.

7. Situmorang P R. Faktor-Faktor yang Berhubungan dengan Kejadian Hipertensi pada Penderita Rawat Inap Di Rumah Sakit Umum Sari Mutiara Medan Tahun 2014. 2015;1(1):67-72. J Ilmu Keperawatan. 2015;1:67-72.

8. Pramantara DPIWR. Hubungan antara Tekanan Darah dan Fungsi Kognitif pada Usia Lanjut. In: Pertemuan Ilmiah Tahunan Ilmu Penyakit Dalam 2002. 2002.

9. Massie BM. Hipertensi Sistemik. Dalam Diagnosis dan Terapi Kedokteran Ilmu Penyakit Dalam. In Jakarta: Salemba Medika; 2002. p. 379-419.

10. Darmojo RBH 150-166. No Title. In: Beberapa Data dan Masalah Hipertensi Di Indonesia Dalam Bunga Rampai Karangan IImu Prof Dr R Boedhi Darmojo Buku II Kardiovaskuler. 1996. p. 150-66.

11. Notoatmodjo S 2007. Promosi Kesehatan dan Ilmu Perilaku. Jakarta: Rineka Cipta; 2007.

12. Effendi W. Faktor-Faktor yang Mempengaruhi Strategi Koping pada Penderita Hipertensi Di Dusun Bakalan dan Jumeneng Kidul Desa Sumberadi Mlati Sleman. 2008. 